\title{
Beihaghi and Political Wings in Ghaznavid Dynasty
}

\author{
Dr. S. Mojtaba Hosseini (Corresponding Author) \\ Assistant Professor at Department of Literature and Humanities \\ Bushehr branch Islamic Azad University, Bushehr, Iran.dr.smho@iaubushehr.ac.ir \\ Mokhtar Abbasi
}

PhD Student, Department of Literature and Humanities, Bushehr branch Islamic Azad University, Bushehr, Iran

\section{Doi:10.5901/mjss.2015.v6n6s2p567}

\section{Abstract}

Abolfazl Beihaghi (385 - 470 Lunar), who was Bu Nasr Meshkan's student, in Ghaznavid era, has pictured over 50 years of Ghaznavid history in his priceless book. In this book he not only recites history, but he also records and criticizes socio-political atmosphere and mannerisms and behaviors of Ghaznavid emirs and politicians. One of the most important subjects mentioned in every corner of what is left of this book, that consists of reports and events of 10 years of Masoud Ghaznavi's reign (421-431 lunar), is the presence of two wings of power, i.e. Mahmoudian (followers of the father) and Masoudian (followers of the son). Beihaghi meticulously states these events. This article proves socio-political values of "Beihaghi history" alongside linguistic, historical and literary research.

Keywords: Beihaghi History, Sultan Mahmoud Ghaznavi, Sultan Masoud, followers of the father, followers of the son, Ghaznavid dynasty.

\section{Introduction}

"Beihaghi History", also known as "Masoudi History" basically recites ten years if Masoud Ghaznavi's reign. Alongside retelling history, Beihaghi actively endeavors to represent mannerisms of politicians and political atmosphere and power ambitions in Ghaznavid dynasty, especially during the reign of Masoud.

In this research we try to characterize political alliances and political power ambitions based on "Beihaghi History".

\subsection{Thesis statement}

Beihaghi's aware and critical view toward socio-political atmosphere, as well as his retelling historical events of Qaznavi dynasty are elements that extend the value of his book. Our main source of research is the book itself, and our method is deriving all documentations that represent political disputes and seeking of power by the two main opposing parties, i.e. Mahmudian (Father) and Masoudian (Son). And because the message is loud and clear we provide little analysis.

\subsection{Justification of the research}

There are two reasons why this research must be dealt with; First, to best clarify capabilities and capacities of this work of art alongside other researches in socio-political field. As Bahrololumi (Lecturer in Tehran University) says "one can derive literary, historical, ethical, social and political benefits from Beihaghi history". Also as Abdul-Hei(Lecturer in Kabul University) states, "What is left of Beihaghi book not only has a literary value but also has much insight about sociopolitical history of Asia." The second reason for this research is to represent political disputes and competitions over power among different patties in ancient Iran.

\subsection{Historical Background}

There have been a great number of researches and studies over literary, linguistic and stylistic qualities of Beihaghi history in the past. Among the researchers are Malik-al-Shoa'ra Bahar, Dr. Ali Akbar Fayyaz, Dr. Seyed Ahmad Hoseini Kazerooni (A Research on Historical and Geographical Glossary of Beihaghi History), Dr. Mohammad Jafar Yahaqi 
(Article: "A Moment with Beihaghi"). Also, the author of this article has another article entitled "Beihaghi and Ethical Criticism of Ghaznavid Dynasty" tried to represent some other qualities of this book (Social and political).

\section{Political Alignments and Power Ambitions during Masoud's Reign and Counteracts to Weaken Each Other}

According to "Beihaghi History", during the reign of Masoud there were two political wings; both of which tried to pull strings wherever possible; but of course one of them was the winner. Those two groups were:

\subsection{Mahmoudian (followers of the father)}

According to Dehkhoda Dictionary, "[Mahmoudian were] those favored by Sultan Mahmoud. On the contrary to those who were favored by Sultan Masoud. (Dehkhoda, 1998: vol 4).

These politicians ruled over the centers of power (generalissimos and head of the bureaus) during the reign of sultan Mahmoud. Sultan Mahmoud demanded to assign Amir Mohammad as his heir, therefore disputes surfaced in the final days of his reign. This group announced Amir Mohammad is king when Mahmoud passed. Some of these men were as follows: Abu Nasr Meshkan, Abu Alhasan Aghili, Kharazmshah Altontash, Hasanak Vazir, Amir Yusuf ben Saboktegin (Masoud's uncle), Bubakr Dabir, Abdurrahman Ghaval, Hajeb Bozorg Ali Gharib. Of course, Ali Gharib later aided the arrest of Amir Mohammad.

\subsection{Masoudian (followers of the son)}

These men of politics followed Masoud and devoted much effort to make Masoud king. As time went by, they gained more and more power and influence. These were not as worthy and experienced as Mahmoudian and they were toddlers to politics. Masoud was well aware of this void. He knew that presence of earnest and wise men like Khaje Hassan Meimandi and Bu Nasr Meshkan was required to strengthen his reign.

Unlike Hasanak Vazir, men like Khaje Hassan were wise enough not to provide excuse for bad deeds of adversaries. So Bu Sahl Zuzani (the key man among Masoudian) was never successful with his plans. But anyway, "Mahmoudian were contented with surviving. (Beihaghi, 1996: p. 183)

These men include: Bu Sahl, Generalissimo Ghazi, Generalissimo Eryargh, Horre Khetli (Masoud's aunt), and Ali Rayez.

Anyway, Mahmoudian were really worried in the first days of Masoud's reign. Ali Gharib, a.k.a. Hajeb Bozorg was arrested because he was ordered to arrest Amir Mohammad and since he was one of Mahmoudian, he disobeyed. As Beihaghi says, "Mahmoudian were very scared when Ali Qharib was arrested; so they prepared themselves to escape"(Beihaghi, 1996: p. 69).

The conspiracy for arresting him was scrupulously planned by Masoudian, and as Ali Gharib himself believed, it was all an excuse to own his property. First, they praised Mengitrag, who was Ali's brother, and had attended Heart, at Sultan Masoud castle's threshold, to deliver the message of Amir Mohammad's Arrest and offered him high office to lure Ali into appearing there. Mengitrag persuaded Ali to visit. Ali Gharib despite his great endeavor to arrest Amir Mohammad was very worried to attend king's threshold, but he had no choice. He told Meshkan, "Beware that one Sultan Masoud s me, you shall no longer hear of me again, for all his sugar coated letters with his own hand writing and all the mercy on my brother are trick.

...these unkind people shall not let the king to let me live; he will grasp my property, thence he shall be dishonorable". (Beihaghi, 1996: p. 58-59)

Before his trip to Herat, he warned Bu Nasr about the danger of Masoudian, "You must beware that the situation is totally different now. One you arrive Herat you will notice this. These new-men have gained much power and amongst them Mahmoudian are considered treacherous and disloyal. Especially now that Busahl has gained power he has assigned rules and he has bribed everybody. This is now all up to Sultan Masoud. If he does not show mercy you will be dead." (Beihaghi, 1996: p. 60)

Ali Gharib headed for Herat with his men and some property.

"And they were informed that Ali will be in Herat with elephants and gold and his men and his properties. They were unbelievably happy. They could not believe he was coming.. They sent men to welcome and encourage him and his brother Mangitrak wrote him letters and told him to haste because everything is as it shall be. They were planning what to 
do. Generalissimo was ordered to attack his men and loot his property one he attends the kings threshold.

When Mangitrak went out he was told that Ali was in dais. When he arrived there thirty slaves seized him and took all his belongings; just what they had done to his brother. (Beihaghi, 1996: p. 66)

This happening really upset Mahmoudian. "Karazmshah (Altuntash) was resperate and numb. He sent messages to Bu Nasr Meshkan and Bul Hassan Aghili that Ali was innocent and what happened to him was not fair and that those new-men would not let any of Mahmoudian live. They plan for my return and I have no hope. Bul Hassan Replied "Please leave me alone, for Sultan Masoud considers me as one of the followers of the father." (Beihaghi, 1996: p. 69)

Others like Abubakr fled their homeland. And as Amir Mohammad was witnessing his escape with a swift camel from Hoktiz castle he sent a man to pursue him. When later he was told about the subject he became very happy and told his kinsmen that "Bubakr Dabir went towards the hot zone, to Kerman and the Iraq and Mecca. I am happy that these mean people did not catch him; for Busahl Zuzani was especially thirsty for his blood". (Beihaghi, 1996: p. 80)

It was clear what was going to happen to people like Hasanak Vazir who supported Amir Mohammad and insulted Sultan Masoud to preserve Mahmoud's will. (Beihaghi, 1996: p. 222)

"When Emir Masoud decided to go from Heart to Balkh, Ali Rayez brought Hasanak to prison and he belittled him and really enjoyed doing that. (Beihaghi, 1996: p. 224) and Busahl "constantly visited Emir in Balkh saying we have to hang Hasanak." (Beihaghi, 1996: p. 224)

On the other hand as Masoud grew stronger some critical Mahmoudi members like Khaje Hassan Meimandi and Bu Nasr Meshkan who was a "farsighted man and without betraying Emir Mahmoud later on managed to gain respect from Masoud." (Beihaghi, 1996: p. 222)

And the remaining members of this group managed to perform more and they tried hard to weaken the opponent group by acts of conspiracy and plots. "Mahmoudians did not cease, until they finally managed to urge Masoud to believe that Eryargh has plotted to bring up a chaos with the help from Ghazi; and if they do not succeed they may leave because most of army are loyal to him" (Beihaghi, 1996: p. 88)

Mahmoudians did not tolerate the presence of Eryargh and Ghazi because both of them were warlords and "Ghazi's rank was not tolerable by Mahmoudian. (Beihaghi, 1996: p. 172) When Emir Masoud heard these he became dubious about these two. "They plotted to outcast Eryargh first; for it they do Ghazi would be alone and easier to defeat. (Beihaghi, 1996: p. 284)

So under these influences, Masoud planned the way his father planned to take him down. They fed Ghazi and Eryargh wine. He "plotted this to arrest Eryargh" (Beihaghi, 1996: p. 294) He entered with his slaves in the middle of the day "when he sat in the Hall, soldiers surrounded him and caught him from both sides in a way that he could not do anything about it". (Beihaghi, 1996: p. 294)

After this, to conquer the next obstacle, "this is what Moahmoudian plotted. Hassan Mehran had a wife. This woman was the godmother of a bondmaid who visited Ghazi's harem very often. They rumored about Amir's decision to arrest Ghazi in a determined night. They told Ghazi about it and terrified him to polt some solution before he face the fate of Eryargh's". (Beihaghi, 1996: p. 299)

Finally Ghazi was so terrified that he fled at night. He was arrested later and when Sultan Masoud found out that he was lured and frightened forgave him and advised him to go to Ghazne which he did.

\subsection{Legitimatizing one's side and destroying the opponent in a guise of religion}

The tragic death of Hasanak is a prime example of how they omitted rivals by an accusation of apostasy. Beihaghi, cunningly draws this image for us. Hasanak's social status is so high that despite old dispute between Masoud and Hasanak, it is not easy to shed his blood. As Beihaghi says, "Despite all the wealth and pride and soldiers, Busahl was like a drop in comparison to Hasanak who was like a river. (Beihaghi, 1996: p. 222)

This represents what a great man Hasanak was; bearing in mind that Beihaghi describes Busahl (Sultan Masoud's special servant) was "a knowledgeable, wellborn, great man". (Beihaghi, 1996: p. 222)

This man was a nemesis of Hasanak and the leading person among Masoudian. He constantly persuaded Masoud to murder him. "Emir told Busahl, "We need an excuse to murder this man" Busahl said, "there is no excuse better than his being apostate and that he accepts gifts from Egyptians to offend Khalifa."' (Beihaghi, 1996: p. 224)

Emir Masoud himself sought revenge and repeatedly talks about Hasanak's remarks to him, "If you ever become king hang us". (Beihaghi, 1996: p. 233)

So under the influence of Busahl he tried to persuade Khaje Ahmad Meimandi to accept Hasanak's execution. "Amir ordered Khaje to sit alone in the Hall because Abdoss wants to deliver him a message. Khaje went to the Hall and Emir asked for me. He said Tell Khaje Ahmed that you khow about Hasanak's Situation. He offended us at the time of my 
father. And after my father was gone he plotted a lot during the reign of my brother. Now that mighty God has granted me this reign, I shall forgive wrongdoers and do not think about the past.

But he talks about this man's belief, "because he accepts gifts from Egyptians while Khalifa disagrees and he disobeyed my father. And they say when the messenger came to Neishabour, he said that Hasanak is an apostate and he must be hung". (Beihaghi, 1996: p. 225)

And people like Bu Nasr Meshkan and Khaje Hasan were unable to do anything about it. And they just witnessed in pain. It is clear that Hasanak's being apostate had no valid foundations; it was only a political gimmickry. For if it was true he would have been hung long ago. Sultan Mahmoud himself precisely rejects this accusation and says, "I myself search the whole world to find Gharmaties. And if I find out that one is Gharmaty I will execute him. If I find out that Hasanak is Gharmaty and if Amir-Almomenin (Khalifa) hears about this and ask me "what are you going to do to him?" I will say, "I myself have raised him as a brother or a child of myself; if he is a Gharmaty, then so am I." (Beihaghi, 1996: $p$. 228)

Here Beihaghi show how they used accusations of apostasy to perish political rivals and adversaries. To best address the illegitimacy of the accusations they directed at Hasanak he signifies three or four signs. The first one is, invention of two so called messengers who they claimed to have come from Baghdad. "They plotted to hang Hasanak and they made up two messengers with the guise of real messengers. And they had letters who claimed to be from Khalifa which ordered to hang Hasanak". (Beihaghi, 1996: p. 232)

Another sign is sending Hasanak's head to Baghdad. "They brought Hasanak to the alter... and stood two messengers so called from Baghdad and they called out to cover his head so that stoning will not squelch it; because we shall sent it to Baghdad". (Beihaghi, 1996: p. 233)

If that is true then why does Hasanak's head is observed again in Busahl (Hasanak's enemy)'s Party? According to Beihaghi, "I heard from Abul Hassan Harili, who was a friend of me and a dear person to Busahl, that one day were were at Busahl's party; and he was drinking. He ordered for Hasanak's dead and they brought it on a tray... We were shocked to see his head and I feinted". (Beihaghi, 1996: p. 235)

In another place, Beihaghi discusses Hasanak's head and argues that sending his head to Baghdad was made up. "and Hasanak was hung for 7 years... so long that nothing was left of his body until finally they were ordered to bring him down and bury him. It was such that no one knew where his head or body are". (Beihaghi, 1996: p. 236)

Another point that we find worthy of mention is Hasanak's silence. As Beihaghi shrewdly writes, "Ahmad Jame-Dar went to Hasanak on a horse and said to him that king says this what you wished for; And you told me to hang you if I ever become king. We wanted to have mercy on you but Emir-el-Momenin (Emir of the Muslims) has declared that you are apostatized. So shall be hung by his command... Hasanak did not response" (Beihaghi, 1996: p. 233).

And finally Beihaghi artistically approves invalidity of this subject in the end of the book. "He (Hasanak) left. And these who planned for him also left... nd they struggled so much for worldly properties; they all went to the same place". (Beihaghi, 1996: p. 234)

According to Beihaghi those powerful men struggled a lot for earthly gains; and great are the number of accusations, all because of the greed for adversaries' properties. Zabihollah Safa criticizes Ghaznavid dynasty and predominance of Turk slaves over Iran and states that, "They were really greedy to collect properties, so were constantly confiscating people's belongings. They urged people to surrender their belongings by accusing them of apostasy". (Safa, 1988: vol. 1, p. 229)

"Beihaghi History" clearly states confiscation of Hasanak Vazir's properties by sultan Masoud.

\section{Conclusion}

"Beihaghi History" is not only a priceless literary work of art in Persian; also it is a book full of political and social criticism. As mentioned in the introduction our main source of research is the book itself, and our method is deriving all documentations that represent political disputes and seeking of power by the two main opposing parties, i.e. Mahmudian (Followers of the father) and Masoudian (Followers of the son).

Later in the article, the quality of political disputes and competitions in Ghaznavi era are represented according the book itself; hence we can conclude that books like Beihaghi History are great works that can be used and studied in other fields of humanities like political history of Iran.

\section{Refrences}

Beihaghi, M. b. H. (1996). Beihaghi History. (3rd Ed). Mashhad: Ferdosy University Publications. 
Dehkhoda, A. A. (1998). Dehkhoda Dictionary. (2nd Ed). Tehran: Tehran University Publication.

Hoseini Kazerooni, S. A. (1995). A Research on Historical and Geographical Glossary of Beihaghi History. (1st Ed). Tehran: Ayat Publications.

Safa, Z. (1988). Anthology of Iranian Literature. (8th Ed). Tehran: Ferdos Publication. 